\title{
Caçadores antigos no sudoeste de Goiás, Brasil
}

Pedro Ignacio Schmitz ${ }^{1}$

\section{Introdução}

No município de Serranópolis ( $52^{\circ}$ Long. O; $18^{\circ} 20^{\prime}$ Lat. S), no sudoeste de Goiás, estão concentrados, num espaço de $25 \mathrm{~km}$, aproximadamente 40 abrigos, dos quais ao menos um certo número apresenta ocupações antigas, cujas datas vão de 11000 anos AP a 8400 anos AP e que denominamos Fase Paranaíba, da tradição Itaparica (Figura 1).

O material recuperado em vários anos de prospecção e escavação é abundante, permitindo um bom estudo do lítico, dos implementos ósseos, dos alimentos animais e ao menos parcialmente do ambiente e suas mundanças.

O trabalho foi realizado numa colaboração entre a equipe de arqueologia do Instituto Anchietano de Pesquisas, UNISINOS e a equipe de arqueologia do Instituto Goiano de Pré-História e Antropologia, UCG, estendendo-se de 1975 a 1982 e somando mil dias/homem de trabalho de campo. O trabalho de laboratório está bem adiantado e o relatório final, a ser publicado por partes, está sendo montado.

\section{O ambiente}

A região de Serranópolis apresenta, do ponto de vista geológico, dois estratos importantes: o inferior, alcançando até $700 \mathrm{~m}$ de altitude, formado pelo arenito eólico da Formação Botucatu; o superior, de basalto toleítico da Formação Serra Geral, que pode alcançar até $1100 \mathrm{~m}$ de altitude. No contato com o basalto, o arenito foi parcialmente silicificado, tornando-se muito mais resistente à erosão, adquirindo boa qualidade para a produção de instrumentos lascados.

O responsável principal pela morfologia atual do terreno é o rio Verdinho, afluente do rio Paranaíba, um dos formadores do rio Paraná. Depois de remover

1 Instituto Anchietano de Pesquisas, UNISINOS. Bolsista do CNPq, BRASIL. os basaltos dos estratos superiores, ele expôs e modelou os arenitos, criando uma paisagem na qual se sucedem hoje, em pequeno espaço, altas chapadas planas, encostas íngremes com abrigos, e um vale aplanado com relictos de erosão sob a forma de mesas e morros arredondados (Figuras 2, 3, 4 y 5).

Os arenitos silicificados encontram-se apenas numa extensão de uns $25 \mathrm{~km}$ ao longo do rio, numa altitude de 500 a $700 \mathrm{~m}$, sobressaindo de 100 a $200 \mathrm{~m}$ sobre o nível atual do rio.

Os abrigos se formaram pela remoção dos estratos pouco resistentes, que estão por debaixo da rocha silicificada. Na medida em que o paredão recuava, iam desabando os seus tetos, criando taludes íngremes semeados de blocos. Nos locais onde a silicificação não se fez apenas na superfície de contato, mas também no interior do arenito, surgiram torres e mesas características, que marcam a paisagem.

Os abrigos formados nos paredões, nas torres, ou debaixo dos blocos caídos nos taludes, costumam ter grandes bocas, pouca profundidade e boa iluminação, com tetos inclinados da frente para o fundo, devido às camadas inclinadas e cruzadas do arenito Botucatu.

Como os abrigos só existem na pequena extensão em que afloram os arenitos silicificados, ali observamos uma extraordinária concentração de material arqueológico, não verificada em outras localidades rio acima ou rio abaixo.

Algumas das condições observadas em Serranópolis existem ao longo da maior parte do vale do rio Verdinho, mas outras lhe são exclusivas: a existência de grandes extensões de abrigos e a abundancia de matéria prima mineral parecem ser fatores decisivos para a concentração verificada e a aparente ausência nas demais áreas.

De um modo geral, no município de Serranópolis, se pode observar uma diversidade grande de 


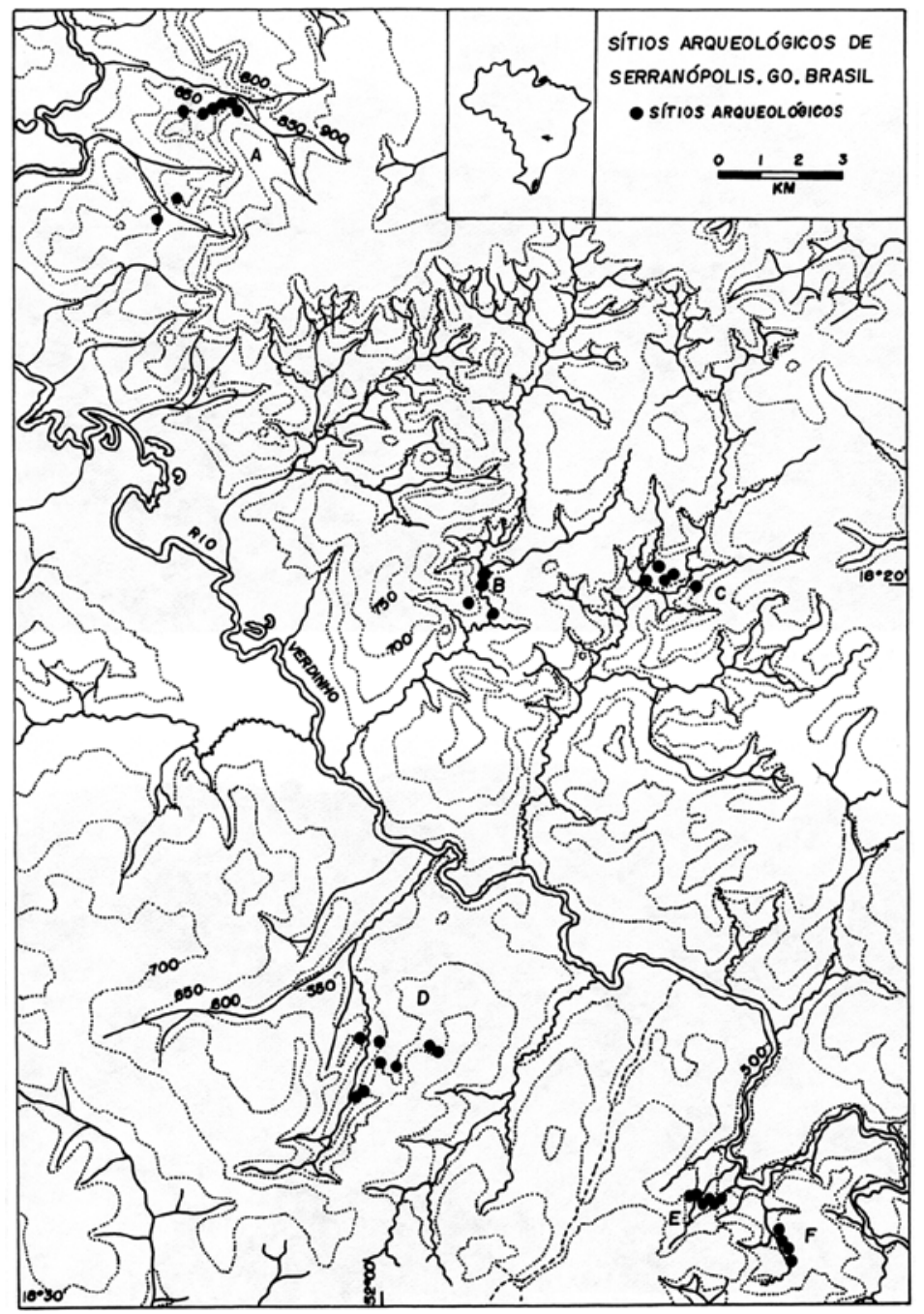

Figura 1. Sítios da Fase Paranaíba, tradiçáo Itaparica no sudoeste de Goiás.

ambientes, muito próximos, devido ao desnível do terreno: nas maiores altitudes existem campos limpos; nos terrenos resultantes da decomposição do basalto cresceram matas fechadas; no vale arenoso e nas chapadas médias cresce o cerrado; nas áreas úmidas e pantanosas ao longo do rio encontra-se uma vegetação palustre muito característica. A fauna acompanha a diversidade ambiental: nos campos há emas; nos cerrados e matos cervídeos, tatus, tamanduás, coatis, pacas, aves menores; nos terrenos úmidos capivaras e antas; nos rios peixes, jacarés, tartarugas; nos paredões rochosos grande número de abelhas melíferas e de caramujos de vários géneros. Além disso os cerrados produzem, especialmente durante a estação das chuvas, uma quantidade inacreditável de frutos, além de fibras e substâncias medicinais.
As chapadas são pouco providas de águas porque os córregos nascem na encosta e, num curso acidentado, mas curto, desembocam no rio.

Nestas condições o local mais favorável para a instalação humana é a encosta, onde se encontram os abrigos, a matéria prima, a água limpa e donde se podem dominar facilmente todos os recursos tanto os da chapada como os do vale e da encosta. A beira do rio, até hoje, é desfavorável para uma instalação, porque pantanosa, sujeita a enchentes e pouco ventilada. $\mathrm{O}$ rio não carrega seixos, mas só areia, e não é limpo, o que retira grande parte do seu interesse.

Não todos os abrigos foram igualmente ocupados porque não ofereciam as mesmas condições: não eram ocupados, ou só esporadicamente, os abrigos 


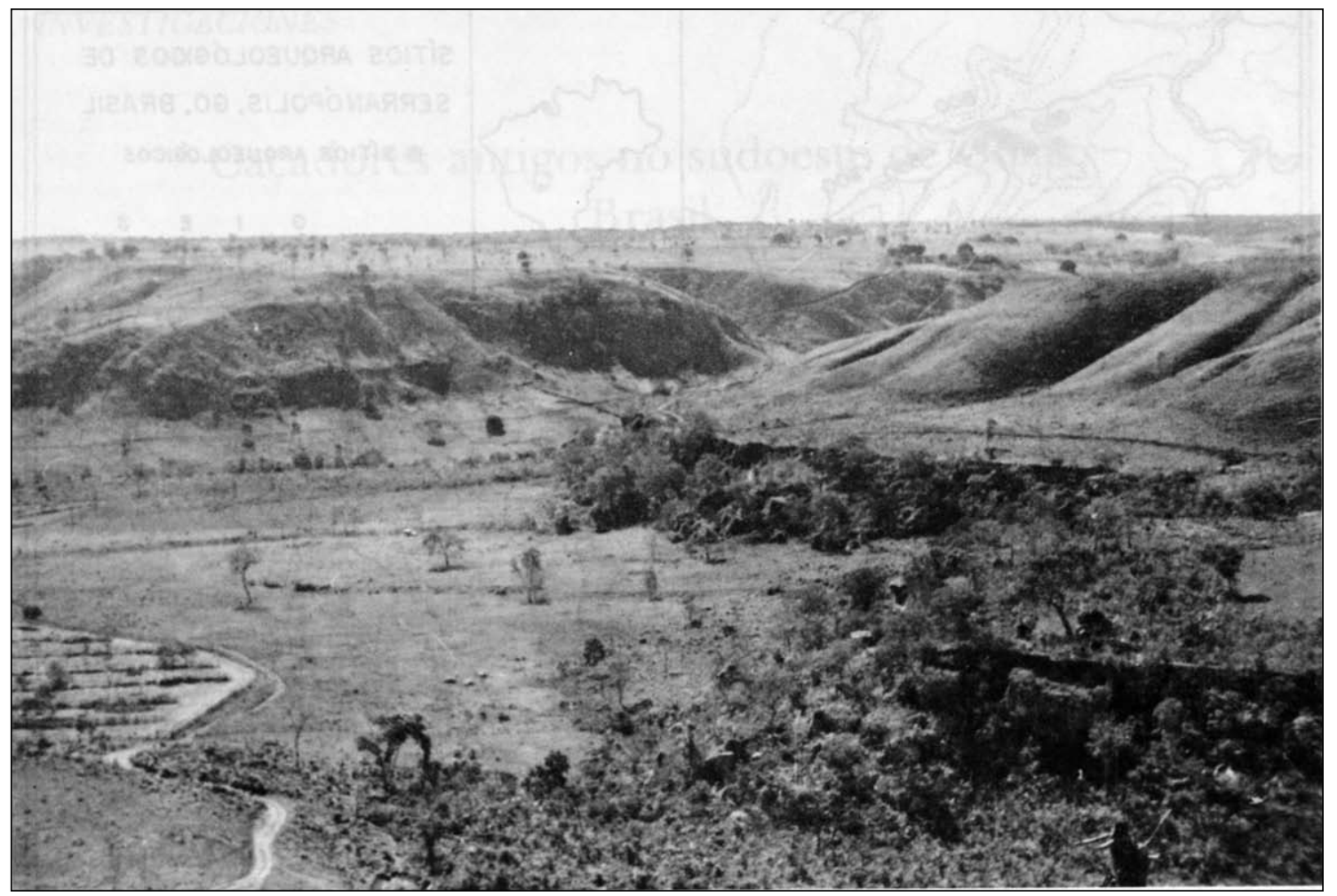

Figura 2. Paisagem de GO-JA-01 e GO-JA-02.

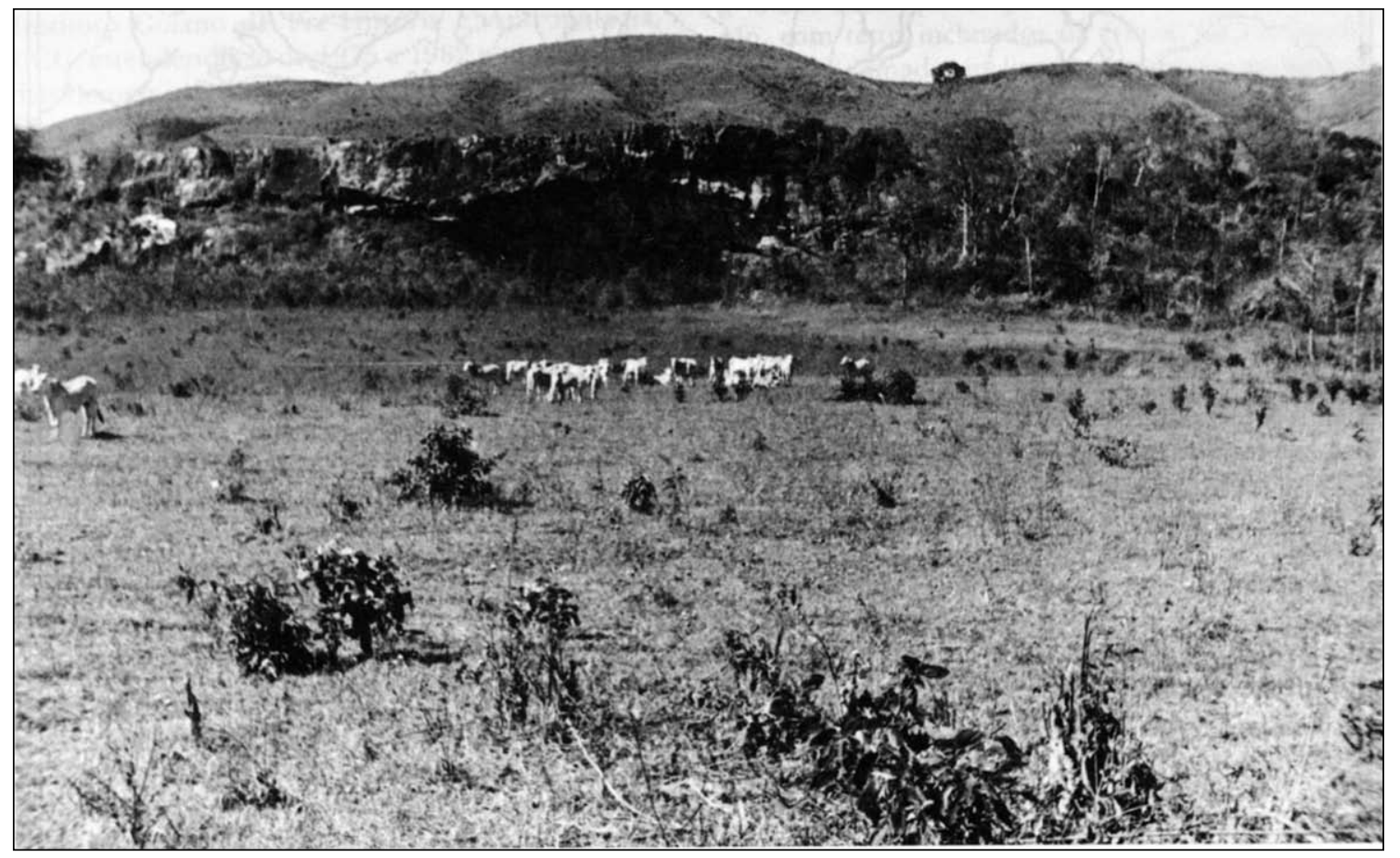

Figura 3. Abrigo GO-JA-01. 


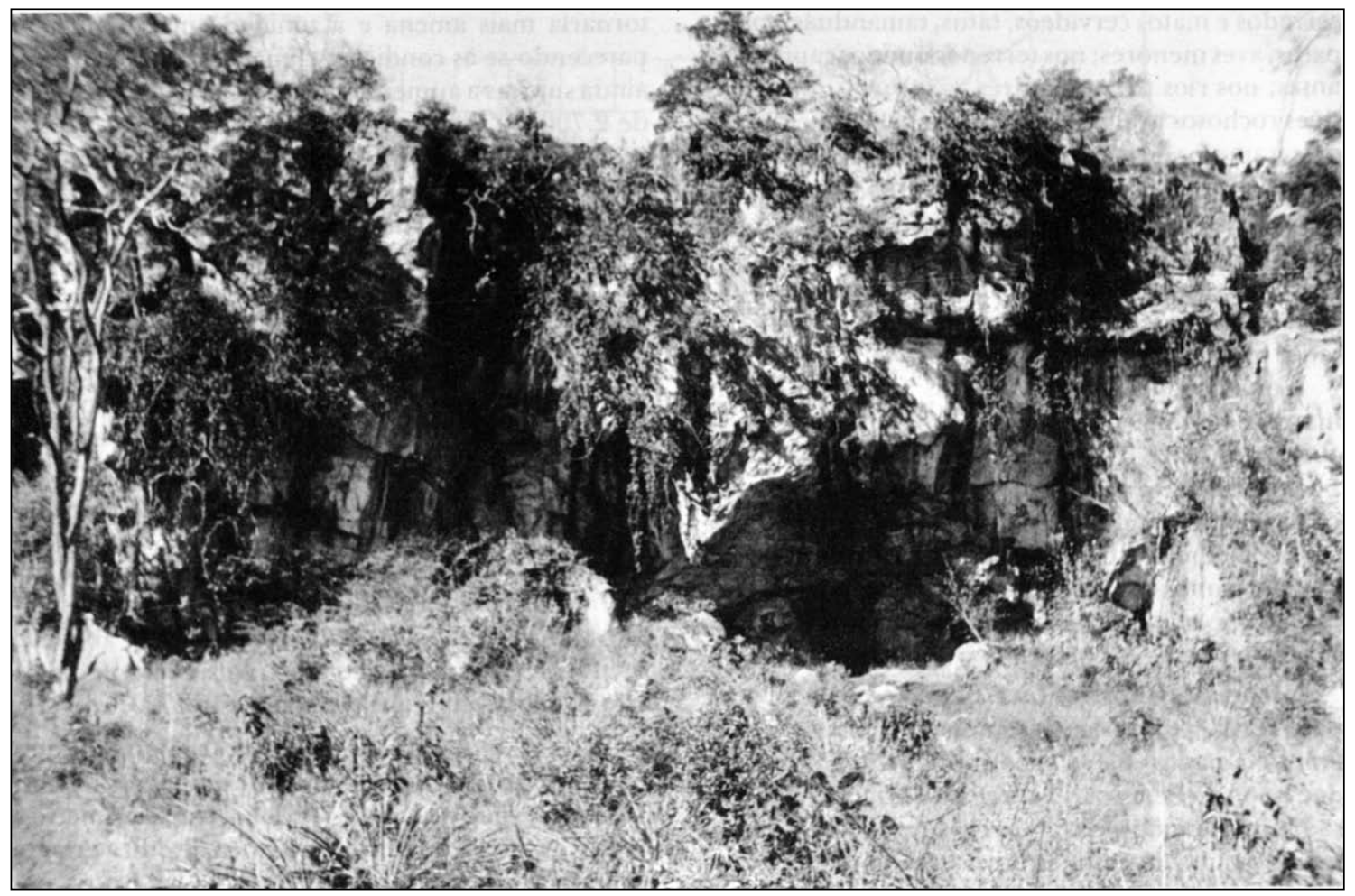

Figura 4. Abrigo GO-JA-02.

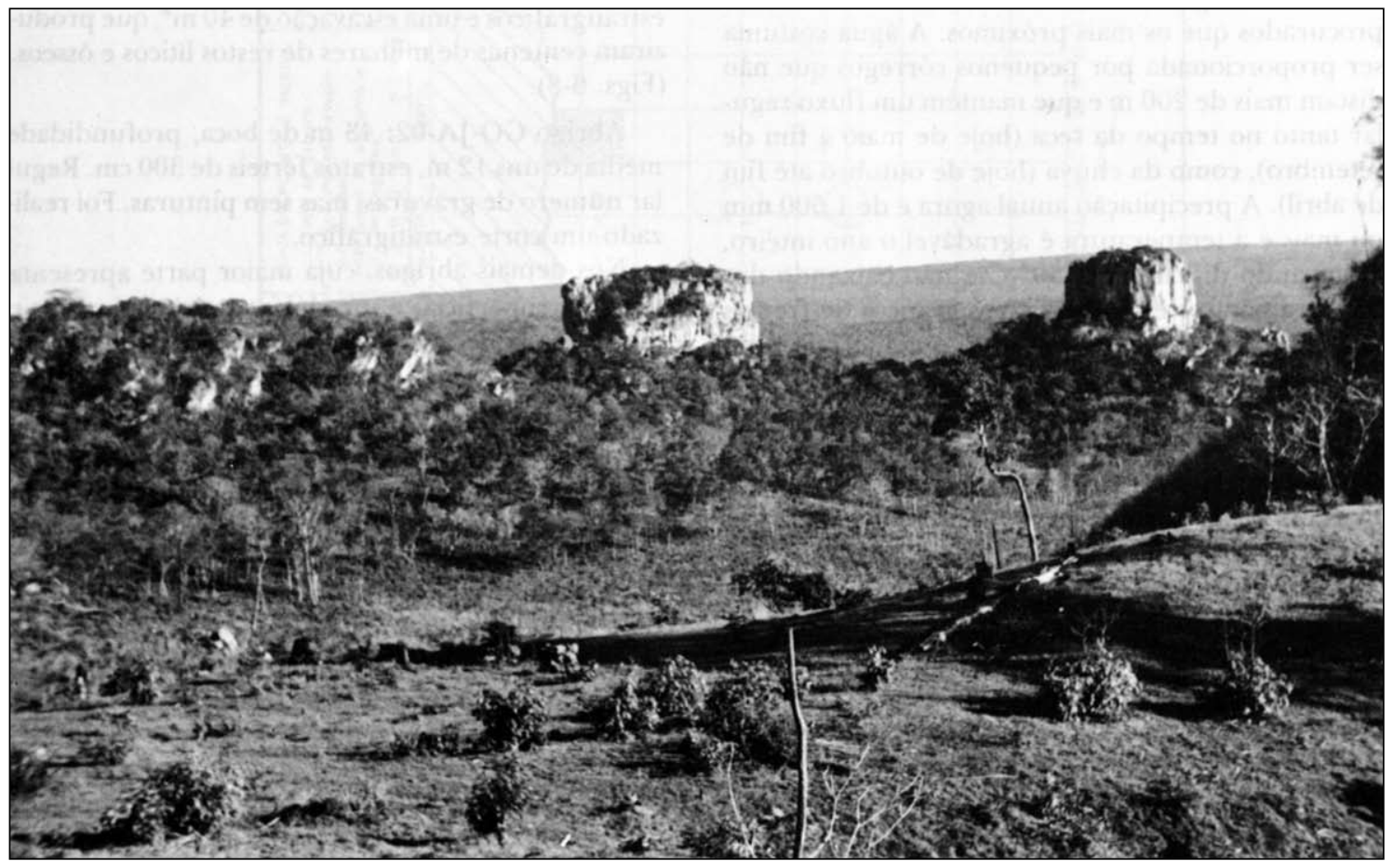

Figura 5. Paisagem do GO-JA-03. 
que não recebem sol de manhã ou ao meio-dia, que são muito úmidos, distantes da água, têm o piso ou taludes muito íngemes. Eram ocupados tanto abrigos pequenos, como grandes, quando as demais condições são iguais, embora não com a mesma intensidade, apresentando os abrigos grandes muito maior quantidade de material que os pequenos. Aparentemente os abrigos mais afastados do rio eram menos procurados que os mais próximos. A água costuma ser proporcionada por pequenos córregos que não distam mais de $200 \mathrm{~m}$ e que mantêm um fluxo regular tanto no tempo da seca (hoje de maio a fim de setembro), como da chuva (hoje de outubro até fim de abril). A precipitação anual agora é de $1500 \mathrm{~mm}$ ou mais e a temperatura é agradável o ano inteiro, alcançando dificilmente $30^{\circ} \mathrm{C}$ e não baixando dos $15^{\circ} \mathrm{C}$, a não ser em muito raros avanços de frentes polares durante o mês de julho, quando pode dar uma noite de geada.

Naturalmente não podemos projetar os recursos atuais no passado remoto sem as devidas correções e o ambiente deve ter sofrido modificações do fim do Pleistoceno ao século passado, isto é, dos primeiros aos últimos caçadores indígenas.

Das camadas arqueológicas dos abrigos estamos deduzindo (Schmitz 1984), que no começo do Holoceno (de 11000 a 8500 anos AP) a região teria sido mais fria e mais seca, sucedendo-se, porém, temporadas mais secas e outras mais úmidas; ao redor de 8500 anos AP percebe-se uma temperatura mais alta, aparentemente sem o correspondente crescimento da umidade, que desembocaria no "ótimo climático" com um máximo de calor e de umidade; ultrapasando este clímax, outra vez a temperatura se tornaria mais amena e a umidade mais reduzida, parecendo-se às condições climáticas atuais, embora ainda sujeitas a aumentos de umidade como ao redor de 2700 e 1700 anos AP.

Ao menos a modificação climática de meados do nono milênio AP se insinua como importante para a compreensão das culturas que descrevemos.

\section{Os sítios}

Praticamente toda a extensão dos $25 \mathrm{~km}$ forma um único nicho, cujo centro e base é o rio Verdinho. Devido aos afloramentos separados de arenito silicificado podemos dividir este nicho em seis pequenos núcleos, onde os abrigos estão concentrados.
A seguir damos informações básicas sobre os núcleos, destacando aqueles sítios que deram material antigo. Generalmente os mesmos também têm material médio e recente. Deixamos de explicitar os sítios que só têm material recente e os locais de abastecimento de matéria prima superficiais, cuja cronologia não foi possível estabelecer com absoluta certeza.

Núcleo A: Na margen esquerda do rio, junto a dois pequenos córregos perenes, onde existem ao menos 10 abrigos, que distam do rio dois a $3 \mathrm{~km}$. É provavelmente o núcleo mais rico devido a grande superfície coberta, à proximidade do rio e dos campos naturais.

Abrigo GO-JA-01: $65 \mathrm{~m}$ de boca, profundidade média de $20 \mathrm{~m}$, estratos férteis de $170 \mathrm{~cm}$. Pinturas e gravuras abundantes. Foram realizados três cortes estratigráficos e uma escavação de $40 \mathrm{~m}^{2}$, que produziram centenas de milhares de restos líticos e ósseos (Figuras 6, 7 y 8).

Abrigo GO-JA-02: $43 \mathrm{~m}$ de boca, profundidade média de uns $12 \mathrm{~m}$, estratos férteis de $300 \mathrm{~cm}$. Regular número de gravuras, mas sem pinturas. Foi realizado um corte estratigráfico.

Nos demais abrigos, cuja maior parte apresenta material superficial e um deles também pinturas e gravuras, ainda não se realizaram cones ou escavações.

Núcleo B: Na margem esquerda do rio, junto a um córrego perene, onde existem quatro abrigos, distantes do rio aproximadamente $6 \mathrm{~km}$. É um dos núcleos mais pobres, porque há pouca superfície coberta, os abrigos estão dispersos e o maior deles é úmido, escuro e não recebe insolação. As demais condições não seriam ruins.

Abrigo GO-JA-20: $70 \mathrm{~m}$ de boca, profundidade média de uns $2 \mathrm{~m}$, estratos férteis de $230 \mathrm{~cm}$. Poucas figuras pintadas. Foi realizado um corte estratigráfico.

Abrigo GO-JA-22: $14 \mathrm{~m}$ de boca, profundidade média de uns $5 \mathrm{~m}$, estratos férteis de mais de $150 \mathrm{~cm}$. Muito poucas pinturas. Foi feito um corte estratigráfico.

No abrigo escuro foi feito um corte estratigráfico, que resultou estéril. No outro abrigo há material, pinturas e gravuras, mas não se realizou nenhum trabalho.

Núcleo C: Na margem esquerda do rio, junto a dois córregos perenes, onde existem cinco abrigos, que 


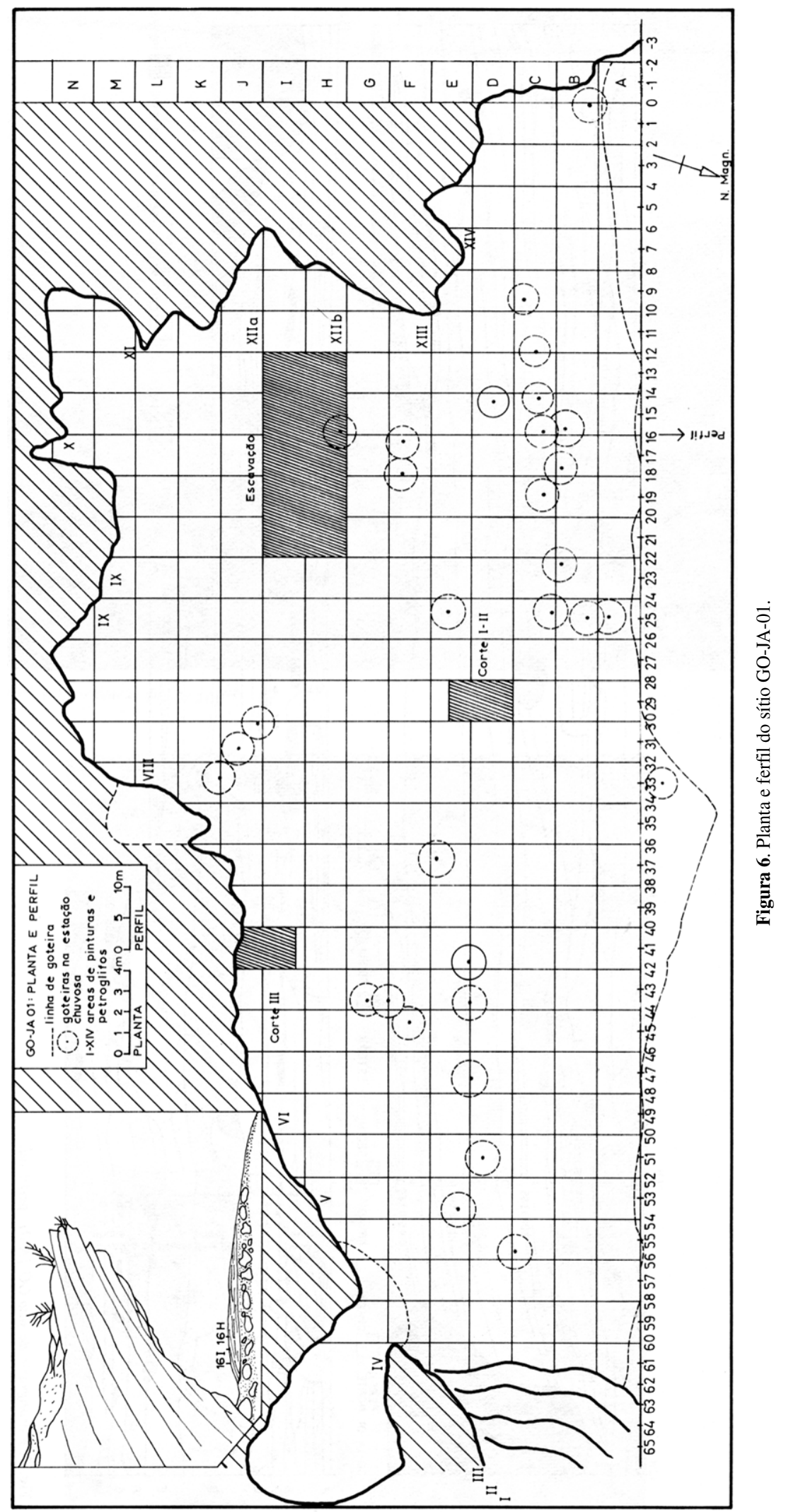


CAÇADORES ANTIGOS NO SUDOESTE DE GOIAS, BRASIL

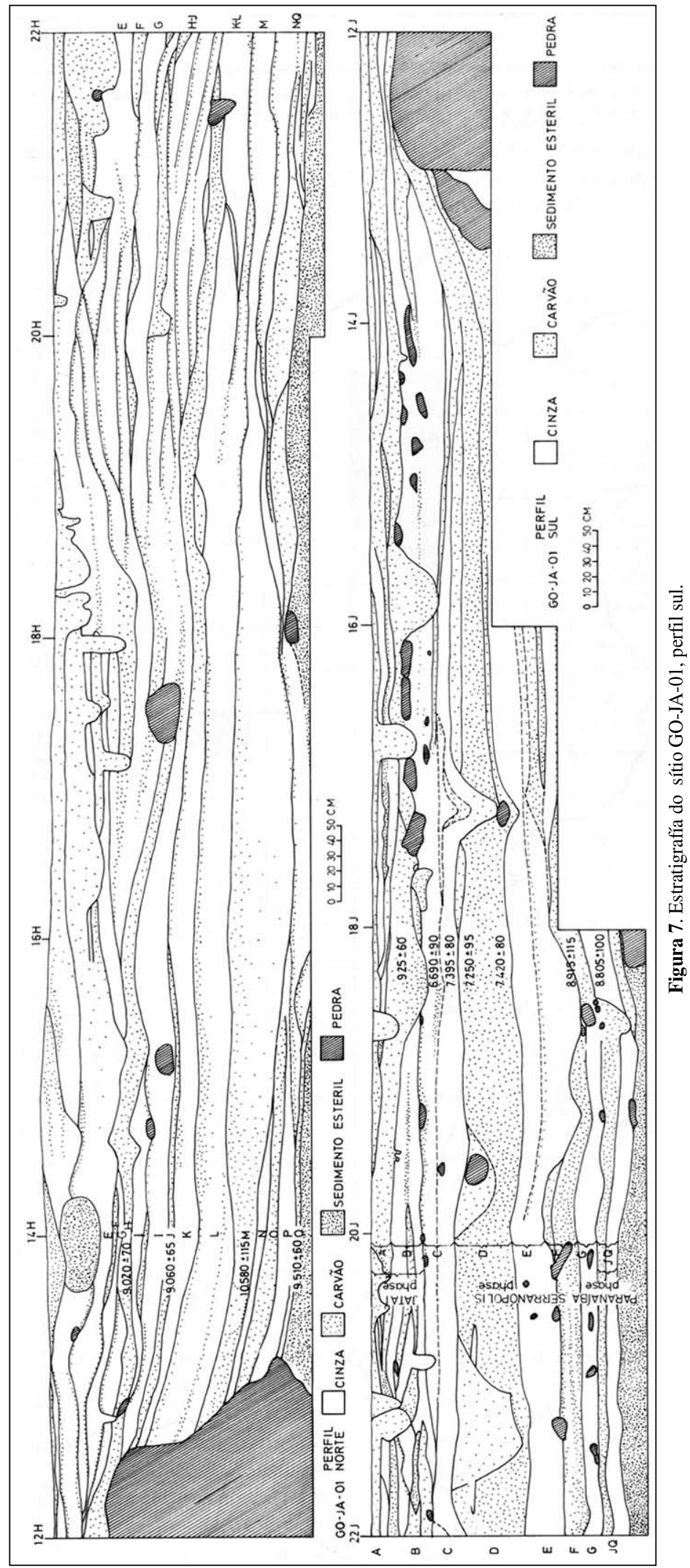




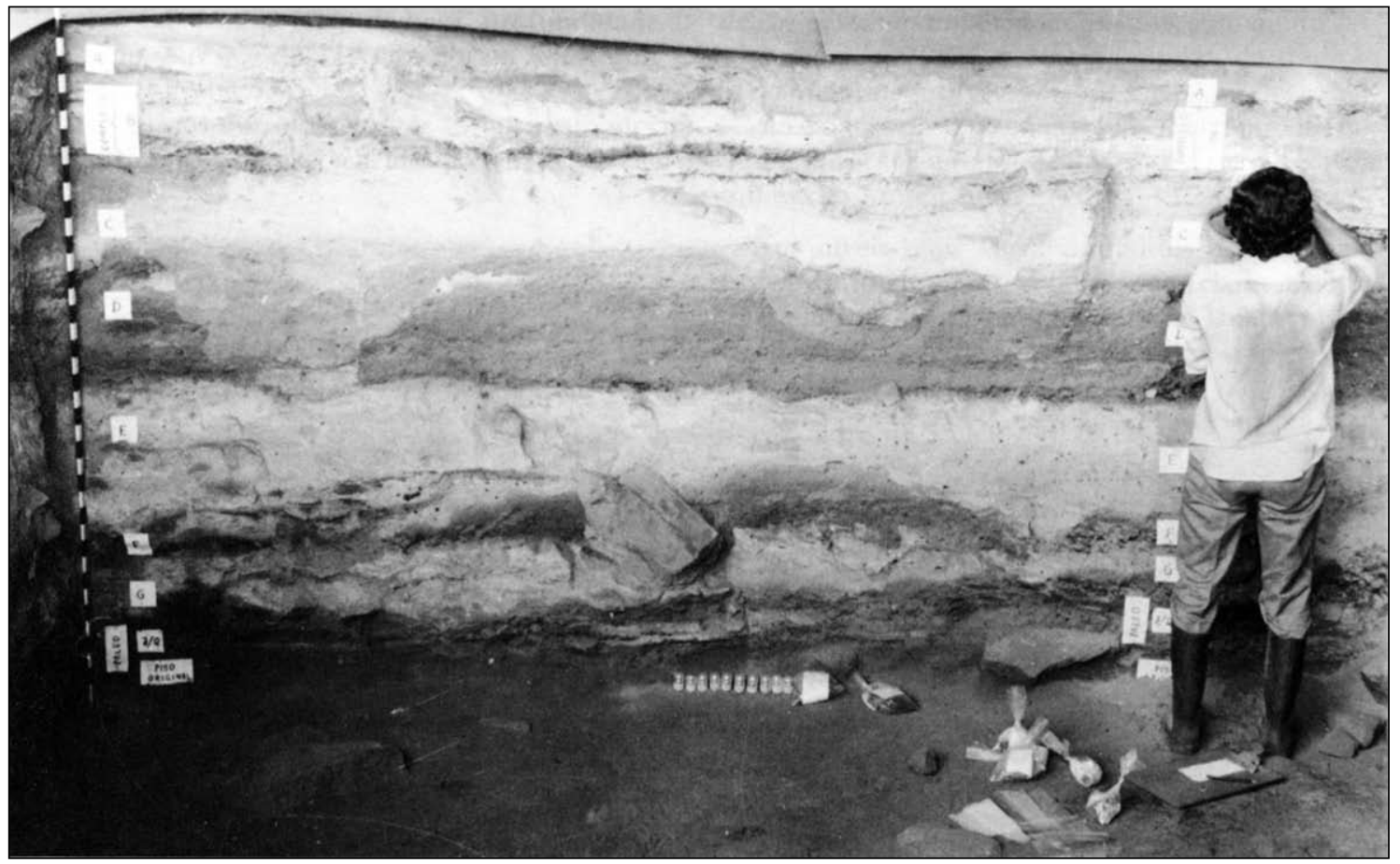

Figura 8. Vista parcial do perfil sul, escavação do GO-JA-01.

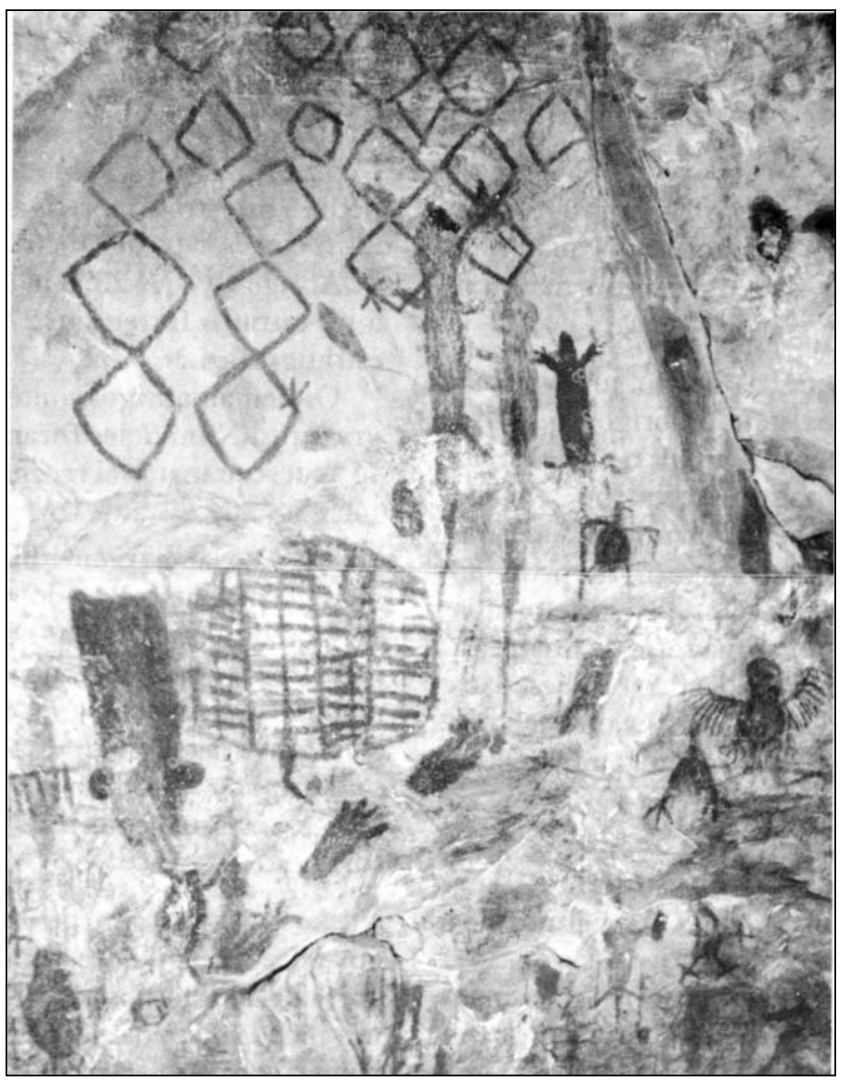

Figura 9. Pintura rupestre, em vermelho, no abrigo GO-JA-03. 


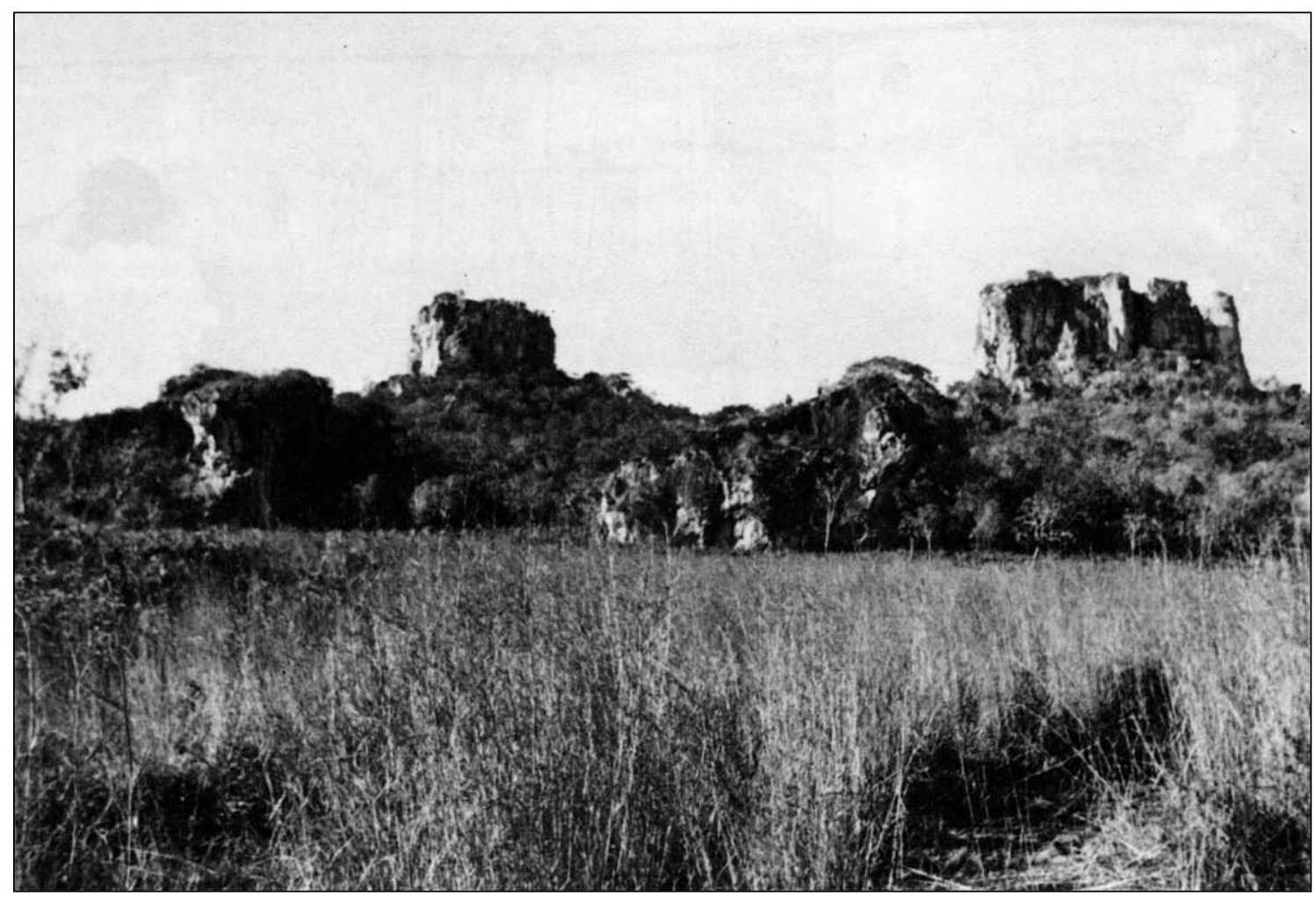

Figura 10. Paisagem do GO-JA-03. No fundo o vale de rio Verdinho.

distam do rio aproximadamente $8 \mathrm{~km}$. É o núcleo mais pobre, porque o espaço coberto é pequeno, a maior parte dos abrigos está com insolação inadecuada, alguns têm o talude íngreme, o espaço útil pequeno ou excessivamente ventilado. Um abrigo tem uma pequena pintura e outro tem uma série de gravuras. Foram feitos cortes estratigráficos em três deles, dando pouquíssimo material e recente; os outros também têm material, mas aparentemente também pouco e recente.

Núcleo $D$ : Na margem direita do rio, junto a um córrego perene, com várias nascentes, junto aos quais existem ao menos oito abrigos. A distancia do rio é de aproximadamente $5 \mathrm{~km}$. É um dos locais mais ricos porque há grande superfície coberta e concentração de outros recursos.

Abrigo GO-JA-03: $80 \mathrm{~m}$ de boca, profundidade média $5 \mathrm{~m}$, estratos férteis até $270 \mathrm{~cm}$. Foram realizados seis cortes estratigráficos (Figuras 9 y 10).

Abrigo GO-JA-26: $8 \mathrm{~m}$ de boca, profundidade de $5 \mathrm{~m}$, estratos férteis até $270 \mathrm{~cm}$. Foi feito um corte estratigráfico.
Os demais abrigos contêm material, pinturas e/ou gravuras. Num deles foram realizados dois cortes, mas só apareceu material recente: o talude é muito íngreme e a água distante.

Núcleo E: Na margem direita do rio, junto a um córrego perene, perto do qual existen ao menos 13 abrigos de vários tamanhos, mas a abundancia de recursos é mediana. A maior parte dos abrigos tem material na superfície e diversos também pinturas e/ou gravuras. Distam do rio $1.5 \mathrm{~km}$.

Abrigo GO-JA-I3c: $20 \mathrm{~m}$ de boca, profundidade $1.50 \mathrm{~m}$, estratos com mais de $290 \mathrm{~cm}$. Foi feito um corte estratigráfico.

Núcleo F: Na margem direita do rio, sobre um córrego agora intermitente, junto ao qual existem quatro abrigos, que distam do rio aproximadamente $1.5 \mathrm{~km}$. É um nicho medianamente rico e nos abrigos há problemas com insolação, taludes íngremes e talvez acesso à água.

Abrigo GO-JA-14: $72 \mathrm{~m}$ de boca, profundidade média $5 \mathrm{~m}$, estratos de $110 \mathrm{~cm}$. Foram feitos dois cortes estratigráficos. 
Também nos outros três abrigos foram realizados cortes estratigráficos, mas sem alcançar materiais antigos.

\section{As fases culturais}

Nos cortes estratigráficos e na escavação aparecem três fases culturais:

1) Nos níveis mais baixos dos abrigos, compostos generalmente de areias frouxas, de coloração marrom avermelhada, com bastante carvão disperso, aparece a fase lítica Paranaíba, da tradição Itaparica.

As 11 datas existentes para a Fase Paranaíba colocamna entre $10740 \pm 75$ anos AP (SI-3111) e 8370 \pm 85 anos AP (SI-5562).

GO-JA-01 deu datas entre 10580 \pm 115 AP (SI-3699) e 9060 \pm 65 AP (SI-3698).

GO-JA-02 deu datas de 10120 \pm 80 AP (SI-3108) e 9195 \pm 75 AP (SI-3107).

GO-JA-03 deu uma data de 9765 \pm 75 AP (SI-3110).

GO-JA-14 deu uma data de $10740 \pm 85$ AP (SI-3111).

GO-JA-26 deu datas de 8880 \pm 90 AP (SI-5563) e $8370 \pm 85$ AP (SI-5562).

Outros sítios, com os mesmos materiais, não foram datados porque era desnecessário, sendo os artefatos suficientes para atribuí-los à mesma fase.

2) Nos níveis intermédios, compostos generalmente de pacotes de cinzas com areia, mais compactados e de cor cinza em tonalidades escuras, com muito carvão, aparece a fase lítica Serranópolis, da tradição Serranópolis.

As sete datas existentes para a fase Serranópolis dão a sua transição ao redor de 9000 AP, sem deixarem muito claro o seu fim.

3) Nos níveis mais altos, compostos de areia com finos estratos de cinzas, generalmente claras, aparece a fase lito-cerâmica Jataí, da tradição Una. Às vezes também restos da fase cerâmica Iporá, tradição Tupiguarani, subtradição Pintada.
As duas datas da Fase Jataí dão o seu início ao redor de 1000 DC.

As três fases distinguem-se tanto pelos sedimentos nos quais aparecem, como pelo material lítico, ósseo e os alimentos, de modo que nos cortes se percebe com bastante facilidade a passagem de uma para outra. Ao menos entre a Fase Serranópolis e a Paranaíba há uma mudança clara e brusca, tanto nos sedimentos, como nos implementos líticos e nos restos de alimentos. Todos os materiais são extremamente abundantes, razão por que a caracterização é bem clara, mas ainda incompleta, uma vez que só parte do material foi analisado.

\section{A Fase Paranaíba}

A indústria lítica da Fase Paranaíba se caracteriza por lâminas grossas unifaciais, com boa técnica lítica e por raros implementos bifaciais, entre os quais algumas pontas pedunculadas. Os artefatos mais abundantes, provenientes dos cortes e da escavação, numa primeira visão, podem ser agrupados da seguinte maneira (Tabla 1).

a) Artefactos unifaciais alongados, no plano principal predominantemente simétricos, sobre lâminas estreitas, trabalhadas em toda a periferia, ou com o plano de lascamento conservado como lado. O lascamento é periférico, sem atingir o interior da face, os bordos regulares, o ângulo dos bordos grande $\left(50-70^{\circ}\right)$. A face interna é lisa, às vezes apresentando bulbo de percussão, outras vezes a parte correspondente da lâmina ou lasca foi removida. A fase externa pode apresentar dorso ou ser aplanada, mantendo às vezes restos de córtex. A extremidade distal pode ser ogival, semicircular ou em ponta. A extremidade proximal em lado ou com retoque abrupto, raramente como a extremidade distal.

Os artefatos foram preparados com percussão dura e direta, a partir de lascas ou lâminas, de $10-20 \mathrm{~cm}$ de comprimento, $4-10 \mathrm{~cm}$ de largura e $2-3 \mathrm{~cm}$ de espessura (Figura 11).

Pelas marcas de desgaste pode-se descrever a funcionalidade desses artefactos como raspadores terminais, ou eventualmente furadores; aproximadamente $2 / 3$ de peça, compreendendo a parte proximal e a mesial, apresentam, em numerosos casos, um desgaste bem visível, sob a forma de esmagamento, nas arestas salientes tanto dos bordos, como da face interna e externa, desgaste que pensamos ter-se originado do uso de algum tipo de invólucro ou cabo. A parte 
distal apresenta, muitas vezes, no bordo direito ou na ponta, desgaste bem nítido sob a forma de microlascamento ou forte esmagamento proveniente da utilização.

Muitas peças foram quebradas pelo uso, sendo a fratura mais comum no limite entre a parte ativa e a passiva (Figura 12).

Entre os instrumentos formalizados, este é o mais comum.

b) Artefàtos unifaciais alongados, predominantemente assimétricos no plano principal, sobre lâminas ou lascas estreitas e finas, trabalhadas em toda a periferia menos o plano de lascamento, que é conservado como lado; ou trabalhados só no bordo direito e parte da extremidade distal, sendo o restante natural.
O lascamento é periférico, sem atingir o interior da face, os bordos retocados regulares, o ângulo do bordo ativo menor que o do anterior $\left(35-50^{\circ}\right)$. A face interna lisa, com o bulbo de percussão freqüentemente visível. A face externa às vezes aplanada, mas generalmente com dorso baixo, localizado mais perto do bordo esquerdo, sendo o bordo direito mais fino e retocado. A extremidade distai pode ser ogival ou semicircular (Figura 13).

Os artefatos foram preparados a partir de lascas ou lâminas com menos de $1 \mathrm{~cm}$ de espessura, por meio de percussão dura e direta.

Pelas marcas de desgaste nas partes proximal, mesial e distal, semelhantes às da variedade anterior, podemos indicar a funcionalidade dos artefatos como raspadores ou raspadeiras sobre lâmina.

\begin{tabular}{|r|l|l|l|l|}
\hline $\begin{array}{c}\text { Fecha } \\
(\mathbf{a n n o s ~ A P )}\end{array}$ & Lab. $^{\mathbf{0}}$ & Unidad & Capa o nivel & Fase \\
\hline $8740 \pm 90$ & N-2347 & Corte I & 12 & Paranaíba \\
\hline $10400 \pm 130$ & N-2348 & Corte I-II & 16 & Paranaíba \\
\hline $925 \pm 60$ & & & & Jataí \\
\hline $6690+90$ & SI-3691 & 18 I & B Inferior & Serranópolis \\
\hline $7395 \pm 80$ & SI-3692 & 18 I & C & Serranópolis \\
\hline $7250 \pm 95$ & SI-3693 & 18 I & D Superior & Serranópolis \\
\hline $7420 \pm 80$ & SI-3694 & 18 I & D Inferior & Serranópolis \\
\hline $8915 \pm 115$ & SI-3695 & 18 I & F & Serranópolis \\
\hline $8805 \pm 100$ & SI-3696 & $18 \mathrm{I}$ & G & Serranópolis \\
\hline $9020 \pm 70$ & SI-3697 & $12 \mathrm{H}$ & H & Serranópolis \\
\hline $9060 \pm 65$ & SI-3698 & $12 \mathrm{H}$ & J & Paranaíba \\
\hline $10580 \pm 115$ & SI-3699 & $12 \mathrm{H}$ & M & Paranaíba \\
\hline $9510 \pm 60$ & SI-3700 & $12 \mathrm{H}$ & Q & Paranaíba \\
\hline
\end{tabular}

Tabla 1. Datas radiocarbónicas para GO-JA-1.

\begin{tabular}{|c|c|c|c|c|l|}
\hline Sítio & $\begin{array}{c}\text { Fecha } \\
(\mathbf{a n ̃ o s ~ A P ) ~}\end{array}$ & Lab. $\mathbf{n}^{\mathbf{0}}$ & Excavación & Nivel/Prof. & Fase \\
\hline GO-JA-2 & $9195 \pm 75$ & SI-3107 & Corte I & $18(170-180 \mathrm{~cm})$ & Paranaíba \\
\hline GO-JA-2 & $10120 \pm 80$ & SI-3108 & Corte I & $26(250-260 \mathrm{~cm})$ & Paranaiba \\
\hline GO-JA-3 & $5720 \pm 50$ & SI-3109 & Corte IV & $16(150-160 \mathrm{~cm})$ & Serranópolis \\
\hline GO-JA-3 & $9765 \pm 75$ & SI-3110 & Corte IV & $22(210-220 \mathrm{~cm})$ & Paranaíba \\
\hline GO-JA-14 & $10740 \pm 85$ & SI-3111 & Corte II & $11(100-110 \mathrm{~cm})$ & Paranaíba \\
\hline
\end{tabular}

Tabla 2. Datas radiocarbónicas para los sítios GO-JA-2, GO-JA-3, y GO-JA-14. 


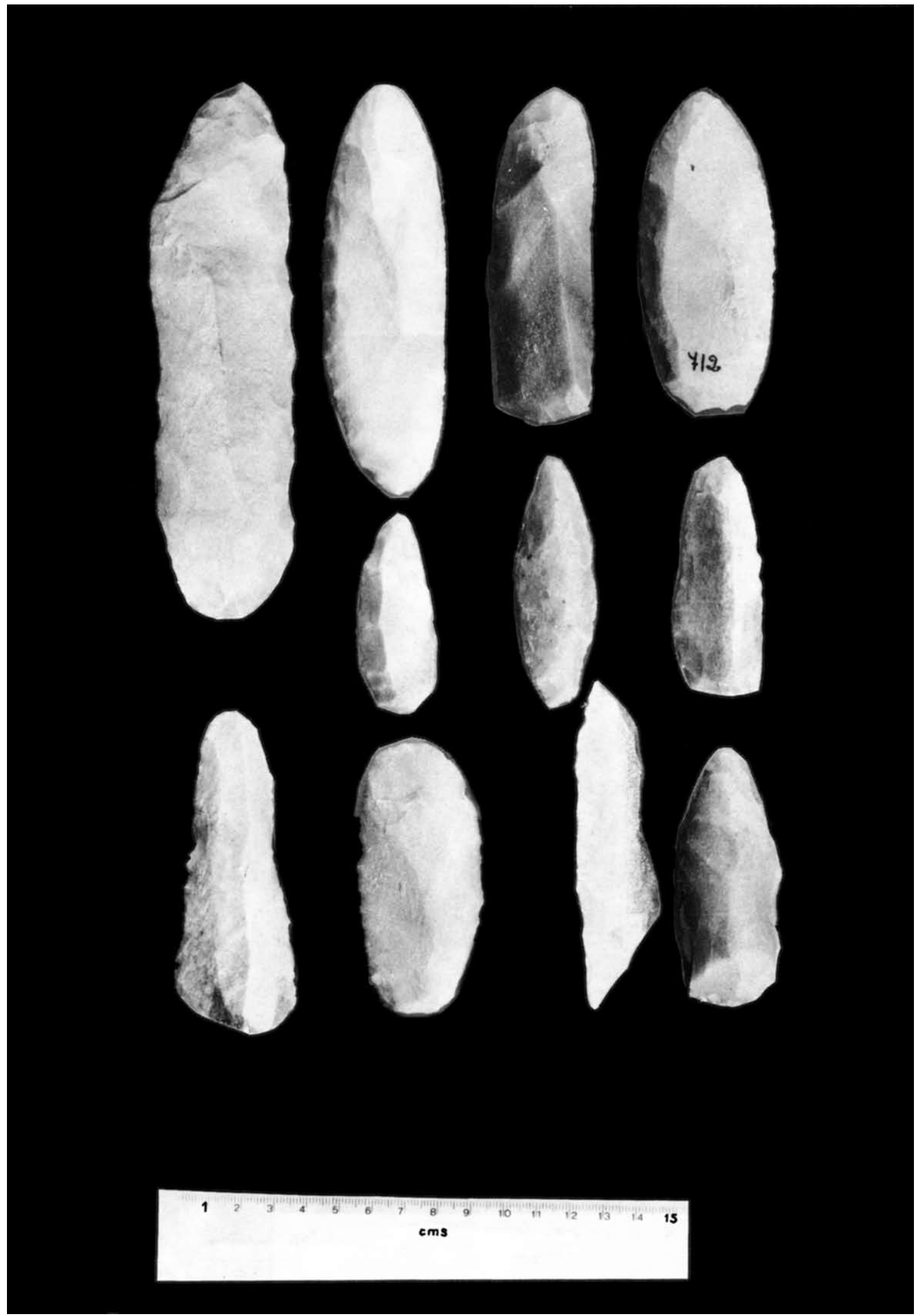

Figura 11. Fase Paranaíba: Artefatos unifaciais. 


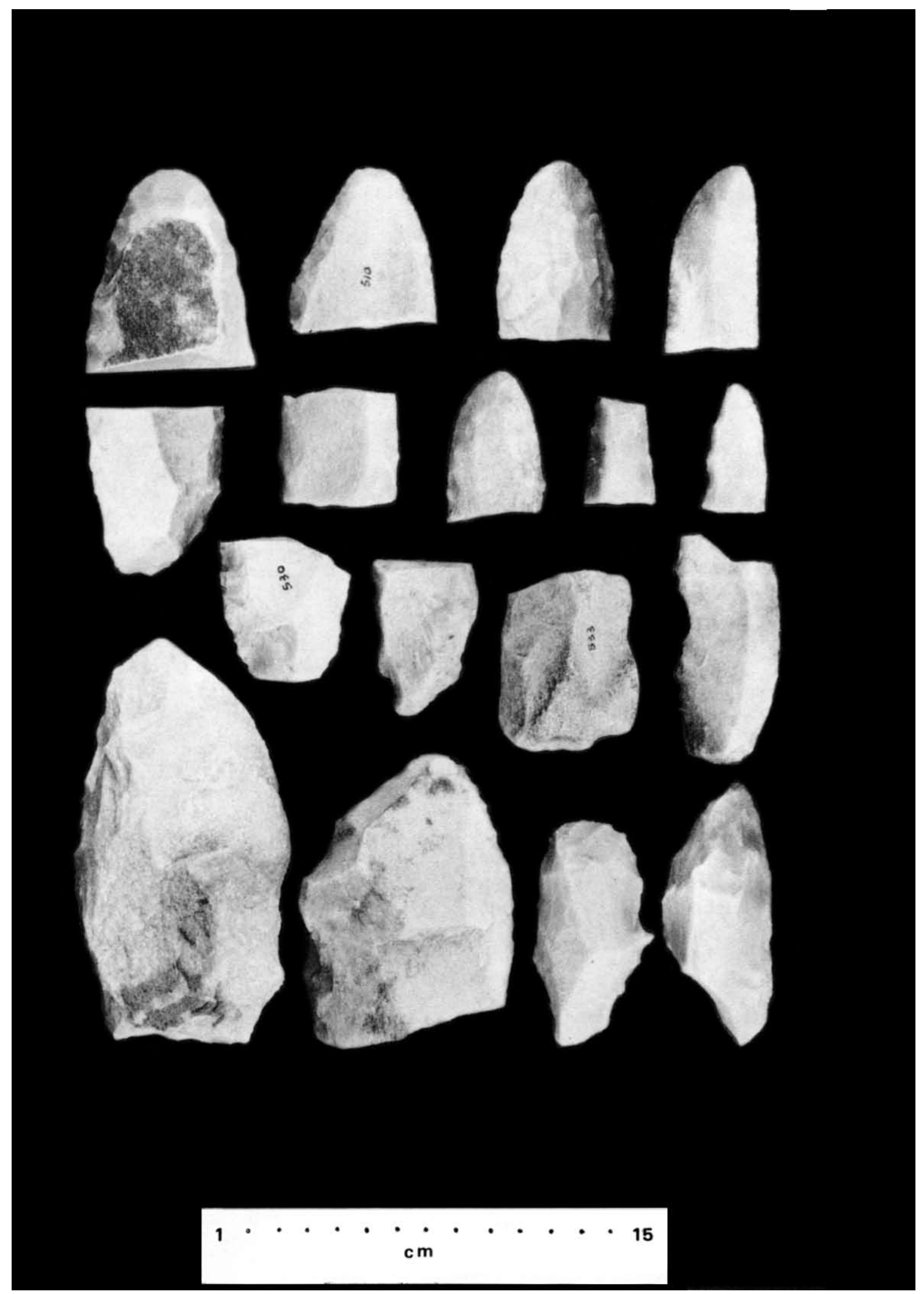

Figura 12. Fase Paranaíba:Artefatos quebrados ou rejeitados na fabricação. 


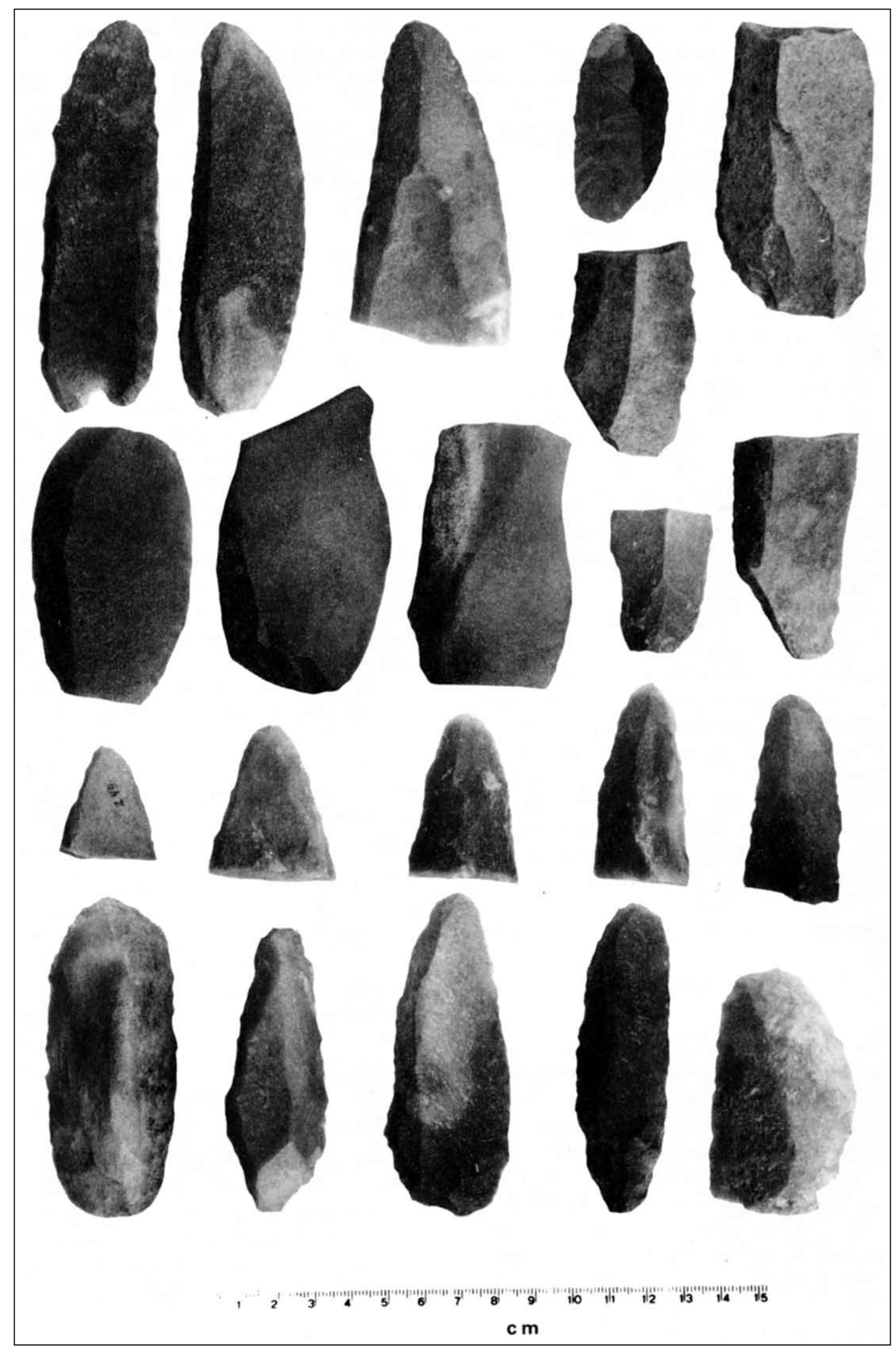

Figura 13. Fase Paranaíba: Artefatos unifaciais. 
Muitas peças foram quebradas pelo uso, sendo a fratura mais comum também aqui no limite entre a parte ativa e a passiva.

Entre os instrumentos formatizados este também é dos mais comuns.

c) Artefatos unifaciais, alongados, assimétricos no plano principal, sobre lascas alongadas, com uma ou duas extremidades truncadas, formando lados, o bordo direito natural ou levemente reforçado, o esquerdo com a aresta dorsal próxima, cortical ou rebaixado. Ângulo do bordo ativo menor que no caso anterior.

Produzidos a partir de lâminas truncadas ou lascas alongadas.

O desgaste se manifesta sob a forma de microlascamento, raramente esmagamento, no bordo ativo, devendo ser consideradas funcionalmente como facas e/ou raspadeiras.

\section{São pouco numerosos.}

d) Artefatos unifaciais, de forma grosseiramente piramidal ou nucleiforme, no plano principal elípticos, ogivais ou irregulares, sobre lascas espessas ou fragmentos de núcleos, trabalhados regularmente em parte ou em toda a periferia, dando com isso origem a gumes regulares de ângulos abertos. A face interna é lisa, a externa pode apresentar dorso alto e resto de córtex. A parte distal costuma apresentar bordo regular formado por lascamentos contínuos curtos e largos, ás vezes estreitos e longos; a parte próximal pode apresentar bordos menos regulares.

Morfologicamente parece tratar-se de raspadores de dorso alto, cuja parte ativa seriam de preferencia a extremidade distal e os bordos longitudinais. Em alguns exemplares os bordos ativos apresentam esmagamentos característicos, provenientes do uso.

No conjunto dos instrumentos formalizados são freqüentes.

e) Artefatos em preparação ou pré-formas das variedades anteriores, generalmente maiores e mais grosseiros, de pouco trabalho secundário e nenhum retoque (Figura 14).
São bastante numerosos.

f) Artefatos unifaciais grandes, nucleiformes ou cuneiformes, no plano principal sem forma padronizada, em perfil plano-convexos, feitos sobre lascas grossas, trabalhados regularmente em parte da periferia, dando com isso origem a gumes regulares de ângulos abertos. A face interna é lisa, a externa é só parcialmente trabalhada, sobrando generalmente pequenas partes do córtex. A parte distal generalmente se compõe de um gume num bordo convexo semi-periférico; a proximal apresenta pouco trabalho.

Morfologicamente parece tratar-se de raspadores laterais altos e convexos sobre lascões irregulares. Não se observam marcas de utilização.

São pouco freqüentes.

g) Artefatos unifaciais sobre lascas ligeiramente alongadas, com abrandamento de bordos excessivamente cortantes por pequenos retoques periféricos. A face interna é lisa, a externa praticamente mantém a superfície da lasca, muito raramente com algum vestígio de córtex.

Pelas marcas de utilização, manifestada como forte alisamento dos bordos cortantes, acompanhados de forte impregnação de material escuro que parece gordura animal, podemos indicar a funcionalidade dos artefatos como raspadores ou raspadeiras, usadas diretamente na mão.

São pouco freqüentes.

h) Artefatos unifaciais espessos, sobre lascas grossas, no plano principal em forma de leque, em perfil planoconvexos, com a periferia oposta ao plano de percussão trabalhada com lascamentos contínuos largos e curtos produzindo um bordo com certa regularidade, mas provido de pequenos dentes e de ângulo muito aberto; o restante da periferia irregular e sem retoque. A face interna lisa, a externa só parcialmente trabalhada, sobrando restos de córtex. A parte distal corresponde à secção retocada, a proximal corresponde ao talão da peça e apresenta pouco trabalho.

Pelas marcas de utilização, manifestada como forte alisamento dos bordos cortantes, podemos indicar a funcionalidade dos artefatos como raspadores, usados diretamente na mão, ou eventualmente com invólucro ou cabo. 


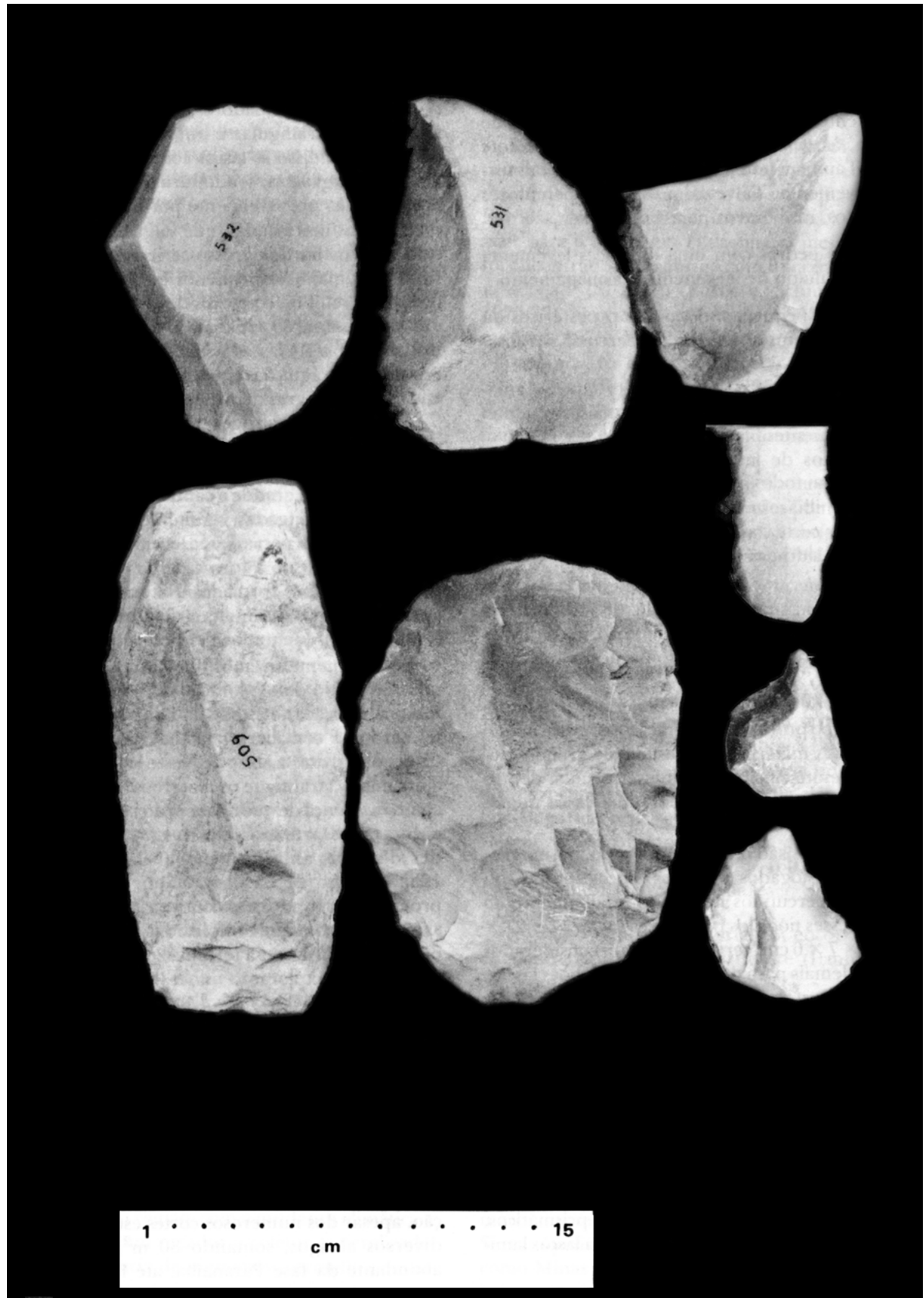

Figura 14. Fase Paranaíba: Em cima artefatos, em baixo: pré-forma, biface grosseiro, lasca, artefatos. 
São poucos exemplares.

i) Artefatos unifaciais, cuneiformes, sobre lascas grossas, no plano principal subretangulares, no perfil plano-convexos, com trabalhos de regularização dos bordos por lascamentos curtos e largos principalmente na parte mesial, o resto pouco ou nada modificado. A face interna lisa, a externa só parcialmente trabalhada, sobrando pequenas parcelas de córtex. A parte distal geralmente sem nenhum retoque é constituída por um gume perpendicular ao eixo longitudinal; a proximal às vezes apresenta rebaixamento do dorso.

Pelas marcas de desgaste, na porção mesial sob a forma de esmagamento na face interna, nos bordos longitudinais e nas saliências da face externa; e na parte distal pelo lascamento irregular do gume, podemos descrever a funcionalidade da peça como um talhador encabado.

São poucos exemplares.

j) Artefatos unifaciais, de forma piramidal, sobre lasca, no plano principal estrelado, no perfil côncavo (ou plano)-convexo, com lascamentos de modelagem em toda a periferia, deixando um bordo denticulado de ângulo aberto. A face interna é lisa, a externa trabalhada na periferia, a parte central plana. A parte ativa é constituída por todo o bordo periférico.

Morfologicamente seria um raspador denticulado, não havendo marcas de utilização.

São poucos exemplares.

k) Três fragmentos de pontas bifaciais: uma parece ser uma extremidade distal, uma um fragmento mesial da lâmina e uma um fragmento proximal mostrando aletas e um pedúnculo de base arredondada. $\mathrm{O}$ lascamento é irregular e cobre completamente as duas faces; ao menos as duas últimas são artefatos incompletos, quebrados na produção.

1) Uma ponta de arenito alisado: grossa, larga, com pedúnculo e aletas, como se fosse uma espécie de modelo de uma ponta de projétil.

m) Um artefato bifacial, com lascamento irregular nas faces e nos bordos, nos quais dois pequenos lados não puderam ser removidos. As arestas do que poderia ser o bordo ativo e as de uma das faces, apresentam desgaste como se fosse de uso (Figura 14). n) Discos lascados, picoteados ou alisados, com aproximadamente $15 \mathrm{~cm}$ de diâmetro e 2 a $4 \mathrm{~cm}$ de espessura, às vezes com uma das faces levemente côncava. Também podem ser seixos chatos, com formato conveniente. Talvez alguns sejam percutores muito gastos, mas outros parecem não ser.

o) Pequenas pedras com uma das faces levemente côncava, resultado de alisamento e esmagamento.

p) Percutores pequenos, discoidais ou esféricos ou em aresta, com muitos sinais de percussão e alisamento.

Existem ainda lascas com algum retoque, regularizando um bordo ou tornando-o mais resistente.

Não são freqüentes.

Os resíduos de lascamento são extremamente abundantes em todos os sítios, podendo-se contar às dezenas de milhares nos sítios de Serranópolis. Ainda não temos certeza em que medida algumas destas lascas teriam sido usadas directamente.

A produção dos artefatos está representada nos próprios abrigos ou sua proximidade; $98 \%$ da matéria prima é o arenito silicificado, que forma grandes porções dos paredões de arenito Botucatu, nos quais estão os sítios.

Num sítio de exploração de matéria prima pudemos observar o processo de extração e transformação do material. A matéria prima usada são grandes nódulos de arenito silicificado, que se formam dentro do arenito e estão cobertos por uma casca menos dura que o miolo silicificado.

Os percutores são outros nódulos do mesmo material que são jogados sobre os blocos iniciais, ou usados para percuti-los no ato do retalhamento. $\mathrm{O}$ tamanho desses nódulos percutores vai de 27 × 21 x $10 \mathrm{~cm}$ a $8 \times 7 \times 6 \mathrm{~cm}$; certamente eram considerados pequenos demais para deles se extrairem boas lascas, havendo fartura de bons blocos.

Os núcleos com lascamento exploratório podem ter medidas de $71 \times 53 \times 37$ a $40 \times 38 \times 23 \mathrm{~cm}$. Os núcleos esgotados, existentes em grande número na periferia da área, vão ainda de 37 x 30 x 27 a 20 x 16 x $15 \mathrm{~cm}$. A maior parte está coberta de cicatrizes de lascas retiradas de posições diferentes, a partir de um plano de percussão qualquer. As lascas extraídas eram 
grandes, irregulares e não preparadas. Ocasionalmente aparecem pequenos núcleos prismáticos, que resultaram da retirada de lâminas ou lascas laminares.

As lascas têm as seguintes características: os planos são lisos (não preparados); a borda interna da lasca (no bulbo) é geralmente larga, raramente estreita, confirmando a utilização de percutores grandes; a saliência do bulbo é mediana a alta; raramente aparecem lascas com pequenas mossas, como se fosem retoques: quando existem podem apresentar-se como pontas entre entalhes, ou bordos com retoque regular como de raspadores; geralmente estas lascas têm a forma triangular e um dos bordos tem estas marcas. Fora disso as lascas costumam ser irregulares, largas e grossas; sendo rara a presença de lâminas, surgidas provavelmente por mero acaso.

As lascas descartadas, que são as que ficaram no sítio, têm os bordos grossos e irregulares; quando finos costumam ser pequenos e côncavos. As lascas de bordos retos ou convexos devem ter sido carregadas para utilização imediata ou transformação em instrumentos. As lascas pequenas e esquirlas foram reunidas pela água das chuvas em depressões onde se encontram em grande número.

No interior dos abrigos foi observado só o processo de acabamento de artefatos, não aparecendo núcleos, nem grandes lascas, mas apenas instrumentos rejeitados e uma grande quantidade de lascas pequenas, finas e alongadas resultantes do processo de acabamento das peças, que devem ter sido trazidas para este lugar sob a forma de lâminas ou lascas já selecionadas e pré-formadas. Naturalmente também aparece um grande número de artefatos acabados, completos ou quebrados pelo uso.

Recentemente tivemos oportunidade de estudar um outro sítio de exploração de matéria prima, da mesma tradição, no estado da Bahía, onde são muito numerosos a céu aberto, não havendo possibilidade de ocupar grutas e abrigos. Neste local encontramos ainda mais claramente os materiais acima indicados, com a diferença de que no meio do refugo também se encontram os artefatos falhados das mesmas variedades descritas anteriormente (Schmitz y Barbosa, 1985). O fato de não haver abrigos habitáveis na proximidade, onde, nas condições de Serranópolis, as pré-formas eram completadas, levou os homens do cerrado da Bahía a terminar os artefatos no próprio sítio de exploração mineral.
A indústria óssea é pouco abundante e variada, sendo a mais comum uma espátula feita de ossos dos pés de cervídeos e um furador feito sobre osso longo; a cornamenta também freqüentemente era usada como compressor ou para outros fins. Os muitos ossos cortados, que se encontram entre os restos de alimentos, indicam ter havido um aproveitamento considerável desse material.

Os sepultamentos correspondentes a esta população, apesar dos numerosos cortes estratigráficos em diversos abrigos, somando $80 \mathrm{~m}^{2}$, com material abundante da Fase Paranaíba, até hoje não foram encontrados.

Os restos de alimentos são muito abundantes em quase todos os abrigos, aparecendo aves, mamíferos, répteis, peixes, mas estando ausentes os moluscos tanto de terra, como da água. Até agora não se encontrou nenhum osso de animal extinto (Jacobus 1983).

Os restos conservados indicam uma atividade de caça, intensa e generalizada, onde estão presentes animais de todos os tamanhos e classes, dos diversos ambientes naturais da região, havendo um pequeno predomínio de cervídeos sobre as demais classes. A coleta se mostra menos acentuada que nas fases posteriores, encontrando-se frutos de palmáceas e outros.

Artefatos líticos, com restos de pigmentos vermelhos, sugerem que a pintura, abundante nos abrigos, começou a ser produzida desde os primeiros acampamentos humanos (Schmitz et al. 1984).

\section{A Fase Serranópolis}

A indústria litica da Fase Serranópolis é muito diferente da anterior: os artefatos de lâminas grossas unifaciais formatizados e bem acabados, desapareceram para dar origem a uma indústria mal definida de lascas irregulares com goivas, bicos, furadores e raspadores pequenos. Continuam os discos e os percutores. As lascas do refugo, encontradas nos estratos, são maiores e mais espessas, também desprendidas por percussão. A manifesta troca de artefatos é acompanhada também por mudanças na matéria prima, aumentando um pouco a utilizaçao da calcedônia em prejuizo do arenito siliciticado.

A indústria óssea, ainda escassa, apresenta furadores, espátulas e anzóis. 
Os sepultamentos são abundantes desde o começo da fase, aparecendo os esqueletos totalmente fletidos, em decúbito lateral, geralmente esquerdo, em covas. Em dois sepultamentos, na proximidade do esqueleto apareceram cornamentas de cervídeos.

Os restos de alimentos também mudam abruptamente, aparecendo moluscos terrestres em grande quantidade e diminuindo os ossos da caça. São usados em proporções semelhantes o Megalobulimus sp. de tamanho grande e os Bulimulídeos, de tamanho pequeno. Todos eles se multiplicam nos lugares ensombrados e úmidos ao longo dos paredões.

Os frutos recuperados são mais abundantes, registrando-se restos de palmáceas e de numerosas plantas do cerrado.

Nota-se que à atividade de caça generalizada do primeiro período, o grupo incorpora novos recursos, que aparecem na região, com a mudança climática, e se transforma num caçador e coletor generalizado.

Pela persistência de pigmentos vermelhos em artefatos desta fase admite-se que a pintura continuou a ser produzida nas paredes dos abrigos.

Produtos cultivados vão aparecer na fase seguinte, 1000 DC.

\section{Comparações}

Materiais semelhantes aos da fase Paranaíba e com datas da mesma ordem aparecem sobre uma larga área do Centro e Nordeste do Brasil, formando a tradição Itaparica.

Dentro do mesmo estado de Goiás, os sítios mais próximos estão a $200 \mathrm{~km}$ para noroeste, em Caiapônia, onde o material aparece em superficie (Schmitz et al. Ms). A $400 \mathrm{~km}$ mais para o norte, em Hidrolina, o mesmo material foi encontrado num abrigo com uma data de 10750 \pm 300 AP (SI-2769) (Barbosa et al. 1976-77). No vizinho município de Niquelandia, Simonsen (1975) descobriu grandes sítios superficiais, um dos quais foi datado em 10605 \pm 125 (Lab. Univ. Stockholm) (Taveira 1985). Na bacia do Paranä, a fase Paranã também reune material semelhante, ainda não datado (Mendonça de Souza et al. 1981).

No estado de Minas Gerais eles aparecem no norte em ao menos cinco abrigos pesquisados por André Prous (Prous et al. 1984) e em ao menos dois abrigos pesquisados por Ondemar F. Dias (Dias 1981 e com. pers. 1984).

No sudoeste da Bahia existem em numerosos sítios superficiais, e recentemente foram encontrados numa gruta calcária (Schmitz et al. 1985).

No Piauí, no município de São Raimundo Nonato, Guidon (1981) menciona material semelhante, começando ao redor de 11000 anos AP.

Em Pernambuco, o material havia sido encontrado pela primeira vez em Petrolândia, dando origem à fase Itaparica, origem da tradição (Calderón 1969). Depois foi encontrado em Bom Jardim e datado entre $11000 \pm 250$ e $9520 \pm 160$ anos AP (MC-1046 e 1056) (Laroche et al. 1977).

No Mato Grosso o material foi encontrado, por enquanto, num abrigo do sudeste (I. Wüst, com. pers. 1984).

No Mato Grosso do Sul também só recentemente e num abrigo (S. M. Copé, com. pers. 1985).

Esta grande dispersão mostra que a tradição Itaparica cobre ao menos o centro e nordeste do Brasil, numa extensão maior que $2000 \mathrm{~km}$.

Nas áreas altas, como Goiás, os restos alimentares que acompanham os característicos artefatos líticos provêm de uma caça generalizada, praticamente sem aproveitamento de moluscos. O aparecimento destes marca a transição para a fase Serranópolis, tradição Serranópolis. Nas áreas mais baixas e mais quentes, como Minas Gerais e Bahía, aparentemente os moluscos são consumidos desde o começo e não se percebe tão claramente uma transição alimentar como a do Planalto no momento da instalação da tradição Serranópolis.

Materiais diferentes, com a mesma cronologia da tradição Itaparica, são encontrados no centro de Minas Gerais e no Rio Grande do Sul.

No centro de Minas Gerais, na grande região de Lagoa Santa, predomina uma indústria de quartzo que pode ter pontas de projétil como em Cerca Grande (Hurt e Blasi 1969) ou não ter pontas, como no Abrigo de Pedro Leopoldo (Laming-Emperaire et al. 1975) e nos da Serra do Cipó (Prous 1981). Talvez, como a correr do tempo e o estudo mais aprofundado dessas indústrias, se consiga entender que elas formam uma 
nova tradição tecnológica, mas de momento o seu significado ainda é obscuro.

Muito diferente é, com certeza a Fase Uruguai, do sudoeste do Rio Grande do Sul (Miller 1976), com numerosas pontas de projetil, que parece ser a origem da tradição Umbu, que vai ocupar as áreas abertas do sul do Brasil até período bastante recente.

A tradição Itaparica parece urna adaptação às savanas tropicais que, desde o começo do Holoceno, se expandiu por cima de todas elas. Estas áreas continuam produzindo principalmente indústrias unifaciais ou simples indústrias de lascas durante vários milênios, em oposição às áreas temperadas do sul, que produzem indústrias com a presença notável de artefatos bifaciais.

\section{Palavras finais}

A maior parte dos achados arqueológicos americanos se registrava até recentemente em áreas temperadas ou frias, dando origem a modelos que pareciam de aplicação universal.

Só recentemente as áreas de savanas tropicais, em sua maior parte concentradas no Brasil, começaram a dar respostas ao menos parcialmente divergentes. A Fase Paranaíba de Serranópolis, Goiás, está mostrando a primeira adaptação holocênica do homen tropical, um caçador generalizado nas áreas menos quentes do baixo planalto do centro, um caçador e coletor generalizado nas áreas mais quentes do nordeste do Brasil; em toda a extensão das savanas usando uma indústria lítica unifacial com uma presença totalmente desprezível de artefatos bifaciais, como poderiam ser pontas de projétil.

A origem dessa tradição, que se espalha sobre uma área de ao menos $2000 \mathrm{~km}$ de extensão, ainda não pôde ser establecida, mas o aparecimento praticamente simultâneo sobre tão grande superfície nos faz postular ocupaçóes anteriores ainda insuficientemente conhecidas. As datas antigas que estão aparecendo no nordeste brasileiro, como São Raimundo Nonato, Piauí, onde remontam até $31500 \pm 950$ anos AP (GIF-6041) (Guidon 1984) ou Coribe, Bahía, onde passam de 20000 anos AP (Schmitz 1984), se não fornecem pontos fixos sobre os quais construir uma teoria da evolução local (Guidon, com. II Reunião Cient. SAB, 1983, 1984), ao menos nos obrigam a ficar atentos quando se apresentam modelos excessivamente simples ou mecânicos.

A evolução da tradição Itaparica, com seus bem acabados artefatos, para uma tradição de lascas com um mínimo de retoque, estendendo-se aparentemente sobre as mesmas savanas tropicais, é outra questão ainda insuficientemente documentada, inclusive para um correto equacionamento da mesma.

Da mesma forma também ainda se encontra insuficientemente datado e organizado o imenso acervo de pinturas rupestres, que se estende sobre as savanas tropicais e acompanha os fenômenos comentados.

A compreensão das adaptações do homem tropical a um ambiente de savanas com duas estações anuais, uma de chuvas e outra de seca, tem crescido nos últimos dez anos de pesquisa, mas vai exigir dos arqueólogos brasileiros ainda um grande esforço de busca, classificação e interpretação.

Agradecimientos Por detrás deste breve apanhado está o trabalho de numerosos pesquisadores não mencionados. Embora não possa nomear todos, preciso indicar os mais importantes: Altair Sales Barbosa, Avelino Fernandes de Miranda, Irmhild Wüst, Sílvia M. Copé, Maira Barberi Ribeiro, Eurípedes Balsanulfo de Freitas e Abreu e Dulce Madalena Rios Pedroso. Da forma a mais destacada preciso registrar o nome do casal Betty Meggers e Clifford Evans que facilitaram uma datação abundante não só dos achados do município de Serranópolis, mas de todo o Programa Arqueológico de Goiás, possibilitando uma comparação segura dos fenómenos das savanas tropicais brasileiras. 


\section{REFERENCIAS CITADAS}

BARBOSA, A. S., P. I. SCHMITZ, A. F. MIRANDA, 197677. Um sitio páleo-índio no médio-norte de Goiás. Novas contribuições ao estudo do páleo-índio de Goiás. Anuário de Divulgação Científica 3 e 4: 21-29.

CALDERON, V., 1969. Nota prévia sobre arqueologia das regiões central e sudoeste do Estado da Bahía, PRONAPA 2, Publ. Av. Mus. Pa. Emílio Goeldi 10: 135-52.

DIAS, O. F., 1981. O Páleo-índio em Minas Gerais. Temas de Arqueologia Brasileira 1 - Paleoíndio. A. S. Barbosa, M. B. Ribeiro, (Eds). Anuário de Divulgação Científica 5 (1978/79/80): 51-54.

GUIDON, N., 1981. Datações pelo $C^{14}$ de sítios arqueológicos cm São Raimundo Nonato, Sudeste do Piauí (Brasil). CLIO, Revista do Curso de Mestrado em História 4: 35-42.

—1984. As primeiras ocupações humanas da área arqueológica de São Raimundo Nonato-Piauí. Revista de Arqueologia 2 (1): $38-46$.

HURT, W. R. y O. BLASI, 1969. O projeto arqueológico Lagoa Santa, Minas Gerais, Brasil (nota final). Arq. Museu Paranaense, Curitiba, NS, Arqueologia 4.

JACOBUS, A. L., 1983. Restos alimentares do sítio GO-JA-01. Serranópolis, Goiás. Nota Prévia. Instituto Anchietano de Pesquisas, UNISINOS, São Leopoldo.

LAMING-EMPERAIRE, A., A. PROUS, A. V. MORAIS y M. C. BELTRÄO, 1975. Grottes et abris de la région de Lagoa Santa. Minas Gerais, Brésil. Cahiers d'Archéologie d'Amérique du Sud, Paris I.

LAROCHE, A. F., A. SOARES E SILVA y J. L. RAPAIRE, 1977. Arqueologia Pernambucana, $C^{14}$. Ginásio Pernambucano, Recife.
MENDONÇA DE SOUZA, A. A. C., S. M. F. MENDONÇA DE SOUZA, I. SIMONSEN, A. DE P. OLIVEIRA y M. A. C. MENDONÇA DE SOUZA, 1981/1982. Seqüência arqueológica da Bacia do Paraná I. Fase pré-cerâmica: Cocal, Paraná e Terra Ronca. Arquivos do Museu de História Natural VI-VII: 81-87.

MILLER, E. T., 1976 Ms. Novos subsídios às pesquisas paleoindígenas no Rio Grande do Sul e Mato Grosso-Brasil.

PROUS, A., 1981. O páleo-índio em Minas Gerais. Temas de Arqueologia Brasileira 1 - Paleoíndio, P. I. Schmitz, A. S. Barbosa, M. B. Ribeiro, (Eds). Anuário de Divulgação Científica 5 (1978/79/80): 61-77.

PROUS, A., P. A. JUNQUEIRA e I. M. MALTA, 1984. Arqueologia do Alto Médio São Francisco, região de Januária e Montalvânia. Revista de Arqueologia 2 (1): 59-71.

SCHMITZ, P. I., 1984. Caçadores e coletores da Pré-História do Brasil. Instituto Anchietano de Pesquisas, UNISINOS, São Leopoldo.

SCHMITZ, P. I. y A. S. BARBOSA, 1985. BA-PR-02: Um sítio de exploração de matéria prima da tradição Itaparica. Anais da III Reunião Científica da SAB, Goiânia (no prelo).

SCHMITZ, P. I., A. S. BARBOSA, M. B. RIBEIRO e I. T. VERARDI, 1984. Arte rupestre no centro do Brasil. Pinturas e gravuras da pre-história de Goiás e oeste da Bahía. Instituto Anchietano de Pesquisas, UNISINOS, São Leopoldo.

SCHMITZ, P. I., A. S. BARBOSA, M. B. RIBEIRO, A. F. MIRANDA, M. DE O. BARBOSA, 1985. Projeto Serra Geral. Anais da III Reunião Cientifica da SAB, Goiânia (no prelo).

SIMONSEN, I., 1975. Alguns sítios da série Bambuí em Goiás (Nota prévia), Museu de Antropologia, UFGO, Goiânia.

TAVEIRA, E. L. DE M. (Ed.), 1985. Museu: Expressão de vida (Catálogo). Museu Antropológico, UFGO, Goiânia. 
